\title{
Amycolatopsis nigrescens sp. nov., an actinomycete isolated from a Roman catacomb
}

\author{
Correspondence \\ Ingrid Groth \\ Ingrid.Groth@hki-jena.de
}

\author{
Ingrid Groth, ${ }^{1}$ Geok Yuan Annie Tan, ${ }^{2}$ Juan M. González, ${ }^{3}$ Leonila Laiz, ${ }^{3}$ \\ Marc René Carlsohn, ${ }^{1}$ Barbara Schütze, ${ }^{1}$ Joachim Wink ${ }^{4}$ \\ and Michael Goodfellow ${ }^{5}$
}

\author{
${ }^{1}$ Leibniz-Institut für Naturstoff-Forschung und Infektionsbiologie e.V., Hans-Knöll-Institut, \\ Beutenbergstrasse 11a, 07745 Jena, Germany \\ ${ }^{2}$ Institute of Biological Sciences (Microbiology), Faculty of Science, University of Malaya, \\ 50603 Kuala Lumpur, Malaysia \\ ${ }^{3}$ Instituto de Recursos Naturales y Agrobiologia, CSIC, Apartado 1052, 41080 Sevilla, Spain \\ ${ }^{4}$ Sanofi-Aventis Deutschland GmbH, Industriepark Hoechst, 65926 Frankfurt (Main), Germany \\ ${ }^{5}$ Division of Biology, University of Newcastle, Newcastle upon Tyne NE1 7RU, UK
}

\begin{abstract}
The taxonomic status of two actinomycetes isolated from the wall of a hypogean Roman catacomb was established based on a polyphasic investigation. The organisms were found to have chemical and morphological markers typical of members of the genus Amycolatopsis. They also shared a range of chemical, molecular and phenotypic markers which served to separate them from representatives of recognized Amycolatopsis species. The new isolates formed a branch in the Amycolatopsis 16S rRNA gene sequence tree with Amycolatopsis minnesotensis NRRL $\mathrm{B}-24435^{\top}$, but this association was not supported by a particularly high bootstrap value or by the product of the maximum-parsimony tree-making algorithm. The organisms were distinguished readily from closely related Amycolatopsis species based on a combination of phenotypic properties and from all Amycolatopsis strains by their characteristic menaquinone profiles, in which tetra-hydrogenated menaquinones with 11 isoprene units predominated. The combined genotypic and phenotypic data indicate that the isolates merit recognition as representing a novel species of the genus Amycolatopsis. The name proposed for this novel species is Amycolatopsis nigrescens sp. nov., with type strain CSC17Ta-90 ${ }^{\top}\left(=\mathrm{HKI} 0330^{\top}=\mathrm{DSM} 44992^{\top}=\mathrm{NRRL}\right.$ B-24473 ${ }^{\top}$.
\end{abstract}

The genus Amycolatopsis Lechevalier et al. 1986 is a member of the family Pseudonocardiaceae Embley et al. 1988 (as circumscribed by Warwick et al., 1994). Members of this family are characterized by the presence of meso-diaminopimelic acid, arabinose and galactose in whole-cell hydrolysates (wall chemotype IV sensu Lechevalier \& Lechevalier, 1970), fatty acids that mainly consist of iso- and anteisobranched components and $N$-acetylated muramic acid and by the lack of mycolic acids (Takahashi, 2001). Amycolatopsis strains can be separated from members of the other genera classified within the family Pseudonocardiaceae by using a range of chemotaxonomic and morphological

The GenBank/EMBL/DDBJ accession numbers for the 16S rRNA gene sequences of strains CSC17Ta-90 ${ }^{\top}$ and CSC17Ta-84 are respectively DQ486888 and DQ486887.

A table giving the cellular fatty acid compositions of strains CSC17Ta$90^{\top}$ and CSC17Ta-84 and A. minnesotensis NRRL B-24435 ${ }^{\top}$ is available as supplementary material in IJSEM Online. markers (Kim \& Goodfellow, 1999) and by genus-specific oligonucleotide primers based on 16S rRNA gene sequences (Tan et al., 2006).

Members of the genus Amycolatopsis are Gram-positive, non-acid-fast, non-motile actinomycetes that form branched vegetative hyphae that undergo fragmentation into rod-like and squarish elements. If present, aerial hyphae may be sterile or differentiate into squarish to ovoid sporelike structures (Chun et al., 1999). The genus encompasses alkaliphilic, mesophilic, thermophilic and pathogenic species, which can be distinguished from one another by using a range of phenotypic properties (SaintpierreBonaccio et al., 2005; Lee, 2006; Lee et al., 2006). At the time of writing, the genus Amycolatopsis comprised 32 recognized species and subspecies, although there is compelling evidence that the genus is grossly underspeciated and that Amycolatopsis fastidiosa should be classified within a different taxon (Tan et al., 2006). The present polyphasic study was designed to determine the taxonomic position of 
two Amycolatopsis-like strains that had been isolated from a hypogean environment. The resultant data show that the isolates represent a novel species of the genus Amycolatopsis.

Strains CSC17Ta-84 (=HKI 0329) and CSC17Ta-90 ${ }^{\mathrm{T}}$ $\left(=\right.$ HKI $\left.0330^{\mathrm{T}}\right)$ were isolated from the wall of the last arcosolium near the exit of the Roman catacomb of St Callistus by touching the stone with a sterile cotton swab and suspending the adherent bacteria in 1:10-diluted organic medium 79 (Prauser \& Falta, 1968). Aliquots of this suspension were spread over nutrient agar (Difco) plates, which were incubated at $28^{\circ} \mathrm{C}$ for 14 days. The isolates were purified and maintained on yeast extract/malt extract agar (ISP medium 2; Shirling \& Gottlieb, 1966) and preserved at $-80{ }^{\circ} \mathrm{C}$ as a mixture of hyphae and fragmentation spores in organic medium 79 broth and glycerol medium that consisted of $\mathrm{K}_{2} \mathrm{HPO}_{4}(1.26 \%), \mathrm{KH}_{2} \mathrm{PO}_{4}(0.36 \%), \mathrm{MgSO}_{4}$ $(0.01 \%)$, sodium citrate $(0.09 \%),\left(\mathrm{NH}_{4}\right)_{2} \mathrm{SO}_{4}(0.18 \%)$ and glycerol $(8.8 \%)$. Stock cultures of the two strains in liquid organic medium 79 supplemented with $5 \%$ DMSO were additionally maintained in the vapour phase of liquid nitrogen.

Bacterial growth for chemotaxonomic investigations of the two isolates and the selected marker strains Amycolatopsis minnesotensis NRRL B-24435 ${ }^{\mathrm{T}}$, Amycolatopsis sacchari DSM $44468^{\mathrm{T}}$ and Amycolatopsis sulphurea IMET $7649^{\mathrm{T}}(=$ ATCC $27624^{\mathrm{T}}$ ) was prepared by cultivating them for $24-48 \mathrm{~h}$ at $28^{\circ} \mathrm{C}$ in liquid organic medium 79 or bacto-trypticase soy broth (Sigma-Aldrich). For MALDI-TOF mass spectrometry (MS) analysis the strains were cultivated on a sterile Sartorius filter (SM 11106) deposited on agar plates with a medium containing soluble starch $(1 \%)$, yeast extract $(0.2 \%)$, glucose $(1 \%)$, glycerol $(1 \%)$, cornsteep liquor $(0.25 \%)$, peptone $(0.2 \%), \mathrm{NaCl}(0.1 \%)$ and $\mathrm{CaCO}_{3}(0.3 \%)$ for 7 days at $28^{\circ} \mathrm{C}$. Morphological and cultural characteristics were studied by cultivating the isolates on ISP media 2, 3, 4 and 5 (Difco) (Shirling \& Gottlieb, 1966) for up to 21 days at $28^{\circ} \mathrm{C}$. Growth parameters were determined by using organic medium 79 . The $\mathrm{pH}$ range for growth was established in shake flasks of liquid medium adjusted to $\mathrm{pH}$ values between 4.5 and 10.0 with either $1 \mathrm{M} \mathrm{HCl}$ or $20 \%$ $(\mathrm{w} / \mathrm{v}) \mathrm{Na}_{2} \mathrm{CO}_{3}$ solution. The cultures were incubated for up to 6 days at $28^{\circ} \mathrm{C}$. Physiological tests, including determination of enzyme activities and susceptibility to antibiotics, were carried out as described by Groth et al. (2003).

Standard HPLC and TLC procedures were used to determine the isomers of diaminopimelic acid in whole-organism hydrolysates (Rhuland et al., 1955; Hasegawa et al., 1983), predominant whole-organism sugars (Becker et al., 1965; Saddler et al., 1991), fatty acids (MIDI system; http:// www.midi-inc.com/), predominant menaquinones (Collins et al., 1977), muramic acid type (Uchida \& Aida, 1984), polar lipids (Minnikin et al., 1979; Collins \& Jones, 1980) and the presence of mycolic acids (Minnikin et al., 1975). For MALDI-TOF MS (Erhard et al., 1997), the samples were collected from cellulose acetate filters, homogenized in a suspension of acetonitrile/methanol $(1: 1)$ and transferred onto a stainless steel template. Each sample was mixed with the matrix (Kroppenstedt et al., 2005) and positive-ion mass spectra were recorded using a MALDI-TOF mass spectrometer (Voyager). The MALDI-TOF MS spectra were analysed by using the Applied Biosystems Software Data Explorer and the peak lists were compared with the SARAMIS software (AnagnosTec).

Chromosomal DNA of isolates CSC17Ta- $90^{\mathrm{T}}$ and CSC17Ta-84 was extracted following the method described by Marmur (1961). PCR amplification of the 16S rRNA genes was achieved using the conserved primers 27F (5'-AGAGTTTGATCCTGGCTCAG) and 1522R (5'-AAGGAGGTGATCCAGCCGCA) (Edwards et al., 1989) under the following conditions: initial denaturation at $95^{\circ} \mathrm{C}$ for $1 \mathrm{~min}$ prior to the addition of BioTaq followed by 35 cycles of $95^{\circ} \mathrm{C}$ for $15 \mathrm{~s}, 55^{\circ} \mathrm{C}$ for $15 \mathrm{~s}$ and $72^{\circ} \mathrm{C}$ for $2 \mathrm{~min}$, and a final extension cycle at $72^{\circ} \mathrm{C}$ for $10 \mathrm{~min}$. Forward and reverse strands of the amplified DNA fragment were sequenced in an ABI 3700 sequencer (Applied Biosystems). The 16S rRNA gene sequences of the strains were aligned manually using the PHYDIT program (available at http:// plaza.snu.ac.kr/ jchun/phydit) against corresponding sequences of representatives of the family Pseudonocardiaceae retrieved from the EMBL and GenBank databases. The algorithm of Jukes \& Cantor (1969) was used to transform sequence dissimilarities into evolutionary distances, and phylogenetic trees were inferred by using the leastsquares (Fitch \& Margoliash, 1967), maximum-parsimony (Fitch, 1971) and neighbour-joining (Saitou \& Nei, 1987) tree-making methods. The topologies of the resultant trees were evaluated in bootstrap analyses based on 1000 replicates. All of the phylogenetic analyses were carried out by using the PHYLIP suite of programs (Felsenstein, 1993) and the resultant phylogenetic trees were viewed by using TREEVIEW (Page, 1996). The root position of the unrooted Amycolatopsis tree based on the neighbour-joining method was estimated by using Prauserella rugosa DSM $43194^{\mathrm{T}}$ as the outgroup.

Almost-complete 16S rRNA gene sequences were generated for isolates CSC17Ta-84 (1459 nt) and CSC17Ta- $90^{\mathrm{T}}$ (1409 nt). Comparison of these sequences with corresponding nucleotide sequences of representatives of the genera classified in the family Pseudonocardiaceae showed that the hypogean organisms belonged to the genus Amycolatopsis (data not shown). In addition, isolates $\mathrm{CSC} 17 \mathrm{Ta}-90^{\mathrm{T}}$ and CSC17Ta-84 shared a range of chemotaxonomic and morphological markers consistent with their assignment to this genus (Lechevalier et al., 1986; Yassin et al., 1993; Takahashi, 2001) as they produced an extensively branched substrate mycelium that fragmented into rod-like elements, formed sparse to moderate aerial hyphae and contained meso-diaminopimelic acid, arabinose and galactose in whole-organism hydrolysates (wall chemotype IV sensu Lechevalier \& Lechevalier, 1970) together with minor amounts of glucose, mannose, rhamnose and ribose. Furthermore, they were characterized by the presence of 
$\mathrm{N}$-acetylated muramic acid and a complex phospholipid pattern consisting of diphosphatidylglycerol, phosphatidylethanolamine, hydroxyphosphatidylethanolamine, phosphatidylglycerol, phosphatidylinositol, phosphatidylserine, two ninhydrin-positive lipids and several uncharacterized glycolipid and polar lipid components (phospholipid pattern 2 sensu Lechevalier et al., 1977). The fatty acid profiles were rich in iso-branched, straight-chain saturated and unsaturated components. Mycolic acids were not detected. Isolates $\mathrm{CSC} 17 \mathrm{Ta}-90^{\mathrm{T}}$ and $\mathrm{CSC} 17 \mathrm{Ta}-84$ were also characterized by the presence of $\mathrm{MK}-11\left(\mathrm{H}_{4}\right)$ as the major menaquinone component (52.4 and $54.3 \%$ of the total, respectively) with smaller proportions of MK-12 $\left(\mathrm{H}_{4}\right)$ (18.1 and $18.2 \%)$, MK-9 $\left(\mathrm{H}_{4}\right)(8.0$ and $8.8 \%)$ and MK$10\left(\mathrm{H}_{4}\right) \quad(9.0$ and $9.1 \%)$. By contrast, representatives of recognized Amycolatopsis species studied to date contain di-, tetra-, hexa- or octa-hydrogenated menaquinones with nine isoprene units as the predominant isoprenologue (Lechevalier et al., 1986; Yassin et al., 1991; Wink et al., 2003; Lee, 2006). Furthermore, the type strain of Amycolatopsis decaplanina is reported to contain a mixture of tetrahydrogenated menaquinones with eight and nine isoprene units (Wink et al., 2004).

The two new isolates shared a 16S rRNA gene sequence similarity of $99.9 \%$, a value that corresponds to a single nucleotide difference at 1408 locations; isolate CSC17Ta-84 has a guanine but isolate CSC17Ta- $90^{\mathrm{T}}$ an adenine at Escherichia coli position 1463 (Brosius et al., 1978). It is evident from Fig. 1 that the new isolates form a branch in the Amycolatopsis gene tree together with the type strain of A. minnesotensis, although this relationship is not supported by a high bootstrap value or by the results from the maximum-parsimony analysis. 16S rRNA gene sequence similarity between isolates CSC17Ta-84 and CSC17Ta- $90^{\mathrm{T}}$ and A. minnesotensis NRRL B-24435 ${ }^{\mathrm{T}}$ was $98.2 \%$, a value equivalent to $25 \mathrm{nt}$ differences at 1458 and 1407 locations. In addition, the two isolates show relatively high $16 \mathrm{~S}$ rRNA gene similarities with the type strains of Amycolatopsis alba (97.5\%), Amycolatopsis azurea (97.4\%), Amycolatopsis keratiniphila subsp. keratiniphila (97.4\%), Amycolatopsis keratiniphila subsp. nogabecina (97.2\%), Amycolatopsis lurida $(97.5 \%)$ and A. sacchari (97.3\%). DNA-DNA relatedness studies were not carried out between isolate $\mathrm{CSC} 17 \mathrm{Ta}-90^{\mathrm{T}}$ and its closest phylogenetic neighbours as it has been shown repeatedly that Amycolatopsis type strains which share much higher 16S rRNA gene similarities than those cited above have DNA-DNA relatedness values well below the $70 \%$ cut-off point recommended by Wayne et al. (1987) for the delineation of strains which belong to the same genomic species (Chun et al., 1999; Labeda et al., 2003; Wink et al., 2003).

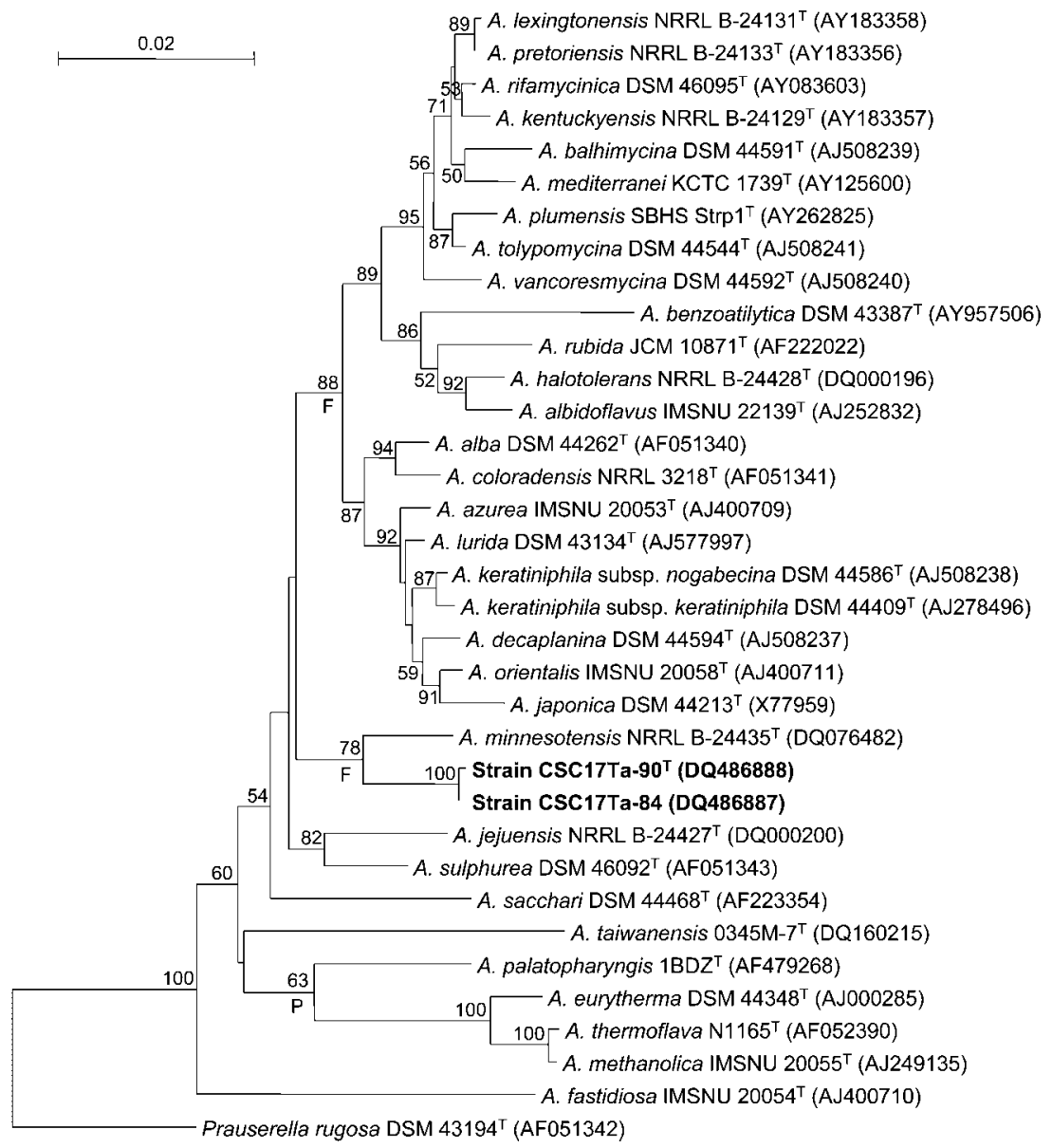

Fig. 1. Neighbour-joining tree (Saitou \& Nei, 1987) based on nearly complete $16 \mathrm{~S}$ rRNA gene sequences showing the relationships between isolates CSC17Ta-84 and $\mathrm{CSC} 17 \mathrm{Ta}-90^{\top}$ and representatives of recognized Amycolatopsis species. $\mathrm{F}$ and $\mathrm{P}$ indicate branches that were also recovered using the least-squares (Fitch \& Margoliash, 1967) and maximum-parsimony (Fitch, 1971) tree-making algorithms, respectively. Numbers at nodes indicate levels of bootstrap support (\%) based on a neighbour-joining analysis of 1000 resampled datasets; only values $\geqslant 50 \%$ are shown. Bar, 0.02 substitutions per nucleotide position. 
Table 1. Differential physiological properties between strain $\mathrm{CSC} 17 \mathrm{Ta}-90^{\top}$ and the type strains of its nearest phylogenetic neighbours in the genus Amycolatopsis

Strains: 1, CSC17Ta-90 ${ }^{\mathrm{T}}$ (identical results for strain CSC17Ta-84 unless indicated); 2, A. alba DSM 44262 ${ }^{\mathrm{T}}$; 3, A. azurea IMSNU 20053 ${ }^{\mathrm{T}}$; 4, A. keratiniphila subsp. keratiniphila DSM $44409^{\mathrm{T}}$; 5, A. keratiniphila subsp. nogabecina DSM 44586 ${ }^{\mathrm{T}} ; 6$, A. lurida DSM 43134 ${ }^{\mathrm{T}}$;, A. minnesotensis NRRL B-24435 $5^{\mathrm{T}}$; 8, A. sacchari DSM 44468 ${ }^{\mathrm{T}}$. Data are from Mertz \& Yao (1993), Goodfellow et al. (2001), Kim et al. (2002), AlMusallam et al. (2003), Wink et al. (2003) and this study. +, Positive; -, negative; w, weakly positive; ND, no data available.

\begin{tabular}{|c|c|c|c|c|c|c|c|c|}
\hline Characteristic & 1 & 2 & 3 & 4 & 5 & 6 & 7 & 8 \\
\hline Colour of aerial mycelium & White to orange & White & Blue & Light grey & Not formed & White & White & White \\
\hline Production of soluble pigment & + & - & + & - & - & - & - & - \\
\hline Nitrate reductase activity & + & - & + & + & - & - & + & + \\
\hline \multicolumn{9}{|l|}{ Decomposition of: } \\
\hline Potato starch & - & + & - & - & - & - & - & - \\
\hline Hypoxanthine & + & + & + & + & + & - & + & - \\
\hline Xanthine & $+^{*}$ & + & - & + & + & + & - & + \\
\hline \multicolumn{9}{|l|}{ Growth on sole carbon sources: } \\
\hline L-Arabinose & + & - & + & + & + & + & - & + \\
\hline D-Fructose & + & + & - & + & + & + & + & + \\
\hline myo-Inositol & + & + & + & + & + & - & + & - \\
\hline D-Raffinose & + & + & + & + & - & - & + & $\mathrm{W}$ \\
\hline L-Rhamnose & $\mathrm{W}$ & - & - & - & + & - & - & + \\
\hline Sucrose & $-{ }^{*}$ & - & + & + & + & - & - & + \\
\hline D-Xylose & + & - & - & + & + & - & $\mathrm{W}$ & + \\
\hline \multicolumn{9}{|l|}{ Enzyme assays (API ZYM): } \\
\hline Alkaline phosphatase & + & + & - & + & + & + & $\mathrm{W}$ & + \\
\hline$\alpha$-Chymotrypsin & + & + & + & + & + & + & - & + \\
\hline Cystine arylamidase & + & + & - & + & + & - & - & + \\
\hline Valine arylamidase & $\mathrm{w}$ & + & - & + & + & - & - & + \\
\hline Esterase (C4) & + & + & - & + & - & - & + & + \\
\hline$\alpha$-Galactosidase & - & - & - & + & + & - & - & - \\
\hline$\beta$-Galactosidase & + & + & + & + & + & + & - & - \\
\hline$\alpha$-Glucosidase & - & + & + & + & + & + & - & $\mathrm{W}$ \\
\hline Lipase (C14) & + & - & - & + & + & + & - & + \\
\hline$\alpha$-Mannosidase & - & + & - & - & + & - & - & - \\
\hline Naphthol-AS-BI-phosphohydrolase & + & + & + & - & + & + & $\mathrm{W}$ & + \\
\hline Trypsin & - & + & + & + & + & + & - & - \\
\hline \multicolumn{9}{|l|}{ Growth at: } \\
\hline $10{ }^{\circ} \mathrm{C}$ & - & - & + & + & ND & + & - & - \\
\hline $40{ }^{\circ} \mathrm{C}$ & + & $\mathrm{W}$ & - & + & + & + & - & + \\
\hline $45^{\circ} \mathrm{C}$ & - & - & - & - & ND & - & - & + \\
\hline \multicolumn{9}{|l|}{ Antibiotic susceptibility ( $\mu$ g per disc): } \\
\hline Kanamycin (30) & - & - & + & + & + & + & - & + \\
\hline Nalidixic acid (30) & - & - & - & - & - & - & + & - \\
\hline Streptomycin (10) & - & - & - & - & - & - & - & + \\
\hline Sulfonamide (200) & - & - & $\mathrm{W}$ & - & $\mathrm{W}$ & $\mathrm{W}$ & + & - \\
\hline Vancomycin (30) & - & - & - & - & - & - & - & + \\
\hline
\end{tabular}

${ }^{\star}$ Strain CSC17Ta-84 grew weakly on sucrose and did not degrade xanthine.

The isolates gave almost identical phenotypic profiles that served to distinguish them from representatives of their phylogenetic neighbours, including A. minnesotensis (Table 1). In addition, they grew well on ISP media 2-7, between 20 and $40{ }^{\circ} \mathrm{C}$ and from pH 5 to 9 . Strains CSC17Ta84 and CSC17Ta-90 ${ }^{\mathrm{T}}$ showed highly similar fatty acid patterns in which 14-methylpentadecanoic acid (iso- $\mathrm{C}_{16: 0}$ ) was the major component (27.7 and $27.1 \%$ of the total fatty acid composition, respectively); fatty acids found in much smaller proportions included $\mathrm{C}_{17: 0}(7.3$ and $9.3 \%), \mathrm{C}_{17: 1}$ cis9 (8.4 and 9.8\%), $\mathrm{C}_{16: 0}(7.4$ and $7.2 \%)$, iso- $\mathrm{C}_{16: 0} 2-\mathrm{OH}$ (7.9 and $6.4 \%)$, iso- $\mathrm{C}_{15: 0}(5.2$ and $5.7 \%), \mathrm{C}_{18: 1}$ cis 9 (4.9 and $4.8 \%)$, iso- $\mathrm{C}_{16: 1}(4.2$ and $4.4 \%)$, anteiso- $\mathrm{C}_{17: 0}$ (3.8 and $3.7 \%), \mathrm{C}_{16: 1}$ cis9 (3.8 and $\left.3.1 \%\right), \mathrm{C}_{18: 0}(3.3 \%)$ and an 

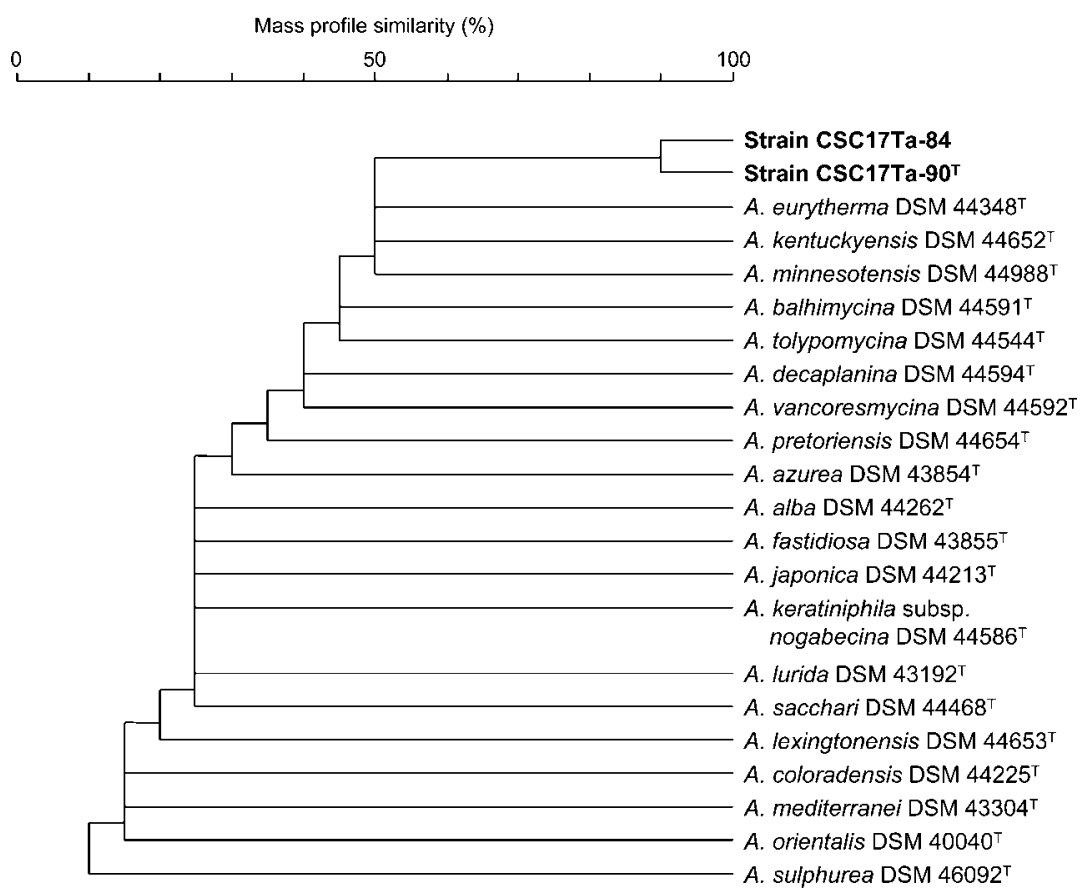

Fig. 2. Dendrogram showing the relationships between strains CSC17Ta-84 and $\mathrm{CSC} 17 \mathrm{Ta}-90^{\top}$ and representatives of the genus Amycolatopsis based on MALDI-TOF MS data. unidentified component (3.7 and 3.0\%). Similar complex fatty acid patterns have been recorded for recognized members of the genus Amycolatopsis (Yassin et al., 1993; Wink et al., 2004). However, differences in the profiles obtained from concurrent fatty acid analyses of the two new isolates and their closest phylogenetic neighbour, $A$. minnesotensis NRRL B-24435 ${ }^{\mathrm{T}}$, clearly distinguished strains CSC17Ta-84 and CSC17Ta-90 ${ }^{\mathrm{T}}$ from this species (see Supplementary Table S1 available in IJSEM Online). The same was true for the MALDI-TOF MS-based fingerprinting data (Fig. 2), which underlined the distinctiveness of strains CSC17Ta-84 and CSC17Ta-90 ${ }^{\mathrm{T}}$ from A. minnesotensis and all other studied less closely related Amycolatopsis species. Furthermore, these data indicated again the close relationship between the two novel organisms as they shared mass similarity values above $70 \%$ (Kroppenstedt et al., 2005).

It is apparent from the genotypic and phenotypic data presented that isolates CSC17Ta-84 and CSC17Ta-90 ${ }^{\mathrm{T}}$ represent a single species that can be distinguished from representatives of all recognized Amycolatopsis species. It is proposed that the isolates be classified in the genus Amycolatopsis as Amycolatopsis nigrescens sp. nov.

\section{Description of Amycolatopsis nigrescens sp. nov.}

Amycolatopsis nigrescens (ni.gres'cens. L. v. nigresco to become black; L. part. adj. nigrescens becoming black).

Aerobic, Gram-positive, non-acid-alcohol-fast, non-motile, catalase-positive actinomycete which forms an extensively branched vegetative mycelium (diameter of hyphae $0.7-0.9 \mu \mathrm{m}$ ) that fragments into squarish rod-like elements. The colour of the substrate mycelium changes from orange to black with the production of a dark reddish-black soluble pigment. The substrate mycelium carries sparse to moderate white or pale-orange aerial hyphae. Optimal growth occurs between 28 and $35^{\circ} \mathrm{C}$, but growth is not evident at either 10 or $42^{\circ} \mathrm{C}$. Grows well between pH 5 and 9 and in the presence of $6.0 \%(\mathrm{w} / \mathrm{v}) \mathrm{NaCl}$, but does not grow at either $\mathrm{pH} 4.5$ or 10 or in the presence of more than $10.0 \%(\mathrm{w} / \mathrm{v}) \mathrm{NaCl}$. Aesculin and urea are hydrolysed and $\mathrm{H}_{2} \mathrm{~S}$ is produced. Casein, hippurate, Tween 80 and tyrosine are degraded but adenine is not. Utilizes acetate, aconitate, citrate, malate, succinate, D-fructose, D-glucose and D-mannitol as sole carbon sources, but not benzoate, DL-tartrate or cellulose. Produces leucine arylamidase, esterase lipase (C8), $N$-acetyl$\beta$-glucosamidase and acid phosphatase, but not $\alpha$-fucosidase or $\beta$-glucuronidase (API ZYM tests). Susceptible to (per disc) chloramphenicol $(30 \mu \mathrm{g})$, imipenem $(10 \mu \mathrm{g})$, ofloxacin $(10 \mu \mathrm{g})$, oxytetracycline hydrochloride $(30 \mu \mathrm{g})$ and rifampicin $(30 \mu \mathrm{g})$, but resistant to (per disc) lincomycin hydrochloride $(2 \mu \mathrm{g})$, meticillin $(5 \mu \mathrm{g})$ and norfloxacin $(10 \mu \mathrm{g})$. Additional phenotypic properties are given in Table 1. Chemotaxonomic characters are typical for Amycolatopsis species, apart from the menaquinone profile, which is characterized by the presence of a large proportion of tetra-hydrogenated menaquinones with 11 isoprene units.

The type strain, CSC17Ta- $90^{\mathrm{T}} \quad\left(=\mathrm{HKI} \quad 0330^{\mathrm{T}}=\mathrm{DSM}\right.$ $44992^{\mathrm{T}}=$ NRRL B- $24473^{\mathrm{T}}$ ), was isolated from the wall of the hypogean Roman catacomb of St Callistus. Strain CSC17Ta-84 (=HKI 0329) is a reference strain.

\section{Acknowledgements}

This work was supported by the European Commission Energy, Environment and Sustainable Development Programme (contract 
EVK4-CT-2000-00028). We are grateful to Renate Schön, Carmen Schult and Christiane Weigel for excellent technical assistance and to Peter Schumann (DSMZ, Braunschweig) for analysing the menaquinones.

\section{References}

Al-Musallam, A. A., Al-Zarban, S. S., Fasasi, Y. A., Kroppenstedt, R. M. \& Stackebrandt, E. (2003). Amycolatopsis keratiniphila sp. nov., a novel keratinolytic soil actinomycete from Kuwait. Int J Syst Evol Microbiol 53, 871-874.

Becker, B., Lechevalier, M. P. \& Lechevalier, H. A. (1965). Chemical composition of cell-wall preparations from strains of various formgenera of aerobic actinomycetes. Appl Microbiol 13, 236-243.

Brosius, J., Palmer, M. L., Kennedy, P. J. \& Noller, H. F. (1978). Complete nucleotide sequence of a $16 \mathrm{~S}$ ribosomal RNA gene from Escherichia coli. Proc Natl Acad Sci U S A 75, 4801-4805.

Chun, J., Kim, S. B., Oh, Y. K., Seong, C.-N., Lee, D.-H., Bae, K. S., Lee, K.-J., Kang, S.-O., Hah, Y. C. \& other authors (1999). Amycolatopsis thermoflava sp. nov., a novel soil actinomycete from Hainan Island, China. Int J Syst Bacteriol 49, 1369-1373.

Collins, M. D. \& Jones, D. (1980). Lipids in the classification and identification of coryneform bacteria containing peptidoglycans based on 2,4-diaminobutyric acid. J Appl Bacteriol 48, 459-470.

Collins, M. D., Goodfellow, M. \& Minnikin, D. E. (1977). Isoprenoid quinones in the classification of coryneform and related bacteria. $J$ Gen Microbiol 110, 127-136.

Edwards, U., Rogall, T., Blöcker, H., Emde, M. \& Böttger, E. C. (1989). Isolation and direct complete nucleotide determination of entire genes. Characterization of a gene coding for $16 \mathrm{~S}$ ribosomal RNA. Nucleic Acids Res 17, 7843-7853.

Embley, T. M., Smida, J. \& Stackebrandt, E. (1988). The phylogeny of mycolate-less wall chemotype IV actinomycetes and description of Pseudonocardiaceae fam. nov. Syst Appl Microbiol 11, 44-52.

Erhard, M., von Dören, H. \& Jungblut, P. (1997). Rapid typing and elucidation of new metabolites of intact cyanobacteria using MALDITOF mass spectrometry. Nat Biotechnol 15, 906-909.

Felsenstein, J. (1993). PHYLIP (phylogeny inference package), version 3.5.1. Distributed by the author. Department of Genome Sciences, University of Washington, Seattle, USA.

Fitch, W. M. (1971). Towards defining the course of evolution: minimum change for a specific tree topology. Syst Zool 20, 406-416.

Fitch, W. M. \& Margoliash, E. (1967). Construction of phylogenetic trees: a method based on mutation distances as estimated from cytochrome $c$ sequences is of general applicability. Science 155, 279-284.

Goodfellow, M., Kim, S. B., Minnikin, D. E., Whitehead, D., Zhou, Z.-H. \& Mattinson-Rose, A. D. (2001). Amycolatopsis sacchari sp. nov., a moderately thermophilic actinomycete isolated from vegetable matter. Int J Syst Evol Microbiol 51, 187-193.

Groth, I., Schütze, B., Boettcher, T., Pullen, C. B., Rodriguez, C., Leistner, E. \& Goodfellow, M. (2003). Kitasatospora putterlickiae sp. nov., isolated from rhizosphere soil, transfer of Streptomyces kifunensis to the genus Kitasatospora as Kitasatospora kifunensis comb. nov., and emended description of Streptomyces aureofaciens Duggar 1948. Int J Syst Evol Microbiol 53, 2033-2040.

Hasegawa, T., Takizawa, M. \& Tanida, S. (1983). A rapid analysis for chemical grouping of aerobic actinomycetes. J Gen Appl Microbiol 29, 319-322.

Jukes, T. H. \& Cantor, C. R. (1969). Evolution of protein molecules. In Mammalian Protein Metabolism, vol. 3, pp. 21-132. Edited by H. N. Munro. New York: Academic Press.
Kim, S. B. \& Goodfellow, M. (1999). Reclassification of Amycolatopsis rugosa Lechevalier et al. 1986 as Prauserella rugosa gen. nov., comb. nov. Int J Syst Bacteriol 49, 507-512.

Kim, B., Sahin, N., Tan, G. Y. A., Zakrewska-Czerwinska, J. \& Goodfellow, M. (2002). Amycolatopsis eurytherma sp. nov., a thermophilic actinomycete isolated from soil. Int J Syst Evol Microbiol 52, 889-894.

Kroppenstedt, R. M., Mayilraj, S., Wink, J. M., Kallow, W., Schumann, P., Secondini, C. \& Stackebrandt, E. (2005). Eight new species of the genus Micromonospora, Micromonospora citrea sp. nov., Micromonospora echinaurantiaca sp. nov., Micromonospora echinofusca sp. nov., Micromonospora fulviviridis sp. nov., Micromonospora inyonensis sp. nov., Micromonospora peucetia sp. nov., Micromonospora sagamiensis sp. nov., and Micromonospora viridifaciens sp. nov. Syst Appl Microbiol 28, 328-339.

Labeda, D. P., Donahue, J. M., Williams, N. M., Sells, S. F. \& Henton, M. M. (2003). Amycolatopsis kentuckyensis sp. nov., Amycolatopsis lexingtonensis sp. nov. and Amycolatopsis pretoriensis sp. nov., isolated from equine placentas. Int J Syst Evol Microbiol 53, 1601-1605.

Lechevalier, M. P. \& Lechevalier, H. A. (1970). Chemical composition as a criterion in the classification of aerobic actinomycetes. Int $J$ Syst Bacteriol 20, 435-443.

Lechevalier, M. P., De Bièvre, C. \& Lechevalier, H. A. (1977). Chemotaxonomy of aerobic actinomycetes: phospholipid composition. Biochem Syst Ecol 5, 249-260.

Lechevalier, M. P., Prauser, H., Labeda, D. P. \& Ruan, J.-S. (1986). Two new genera of nocardioform actinomycetes: Amycolata gen. nov. and Amycolatopsis gen. nov. Int J Syst Bacteriol 36, 29-37.

Lee, S. D. (2006). Amycolatopsis jejuensis sp. nov. and Amycolatopsis halotolerans sp. nov., novel actinomycetes isolated from a natural cave. Int J Syst Evol Microbiol 56, 549-553.

Lee, S. D., Kinkel, L. L. \& Samac, D. A. (2006). Amycolatopsis minnesotensis sp. nov., isolated from a prairie soil. Int J Syst Evol Microbiol 56, 265-269.

Marmur, J. (1961). A procedure for the isolation of deoxyribonucleic acid from microorganisms. J Mol Biol 3, 208-218.

Mertz, F. P. \& Yao, R. C. (1993). Amycolatopsis alba sp. nov., isolated from soil. Int J Syst Bacteriol 43, 715-720.

Minnikin, D. E., Alshamaony, L. \& Goodfellow, M. (1975). Differentiation of Mycobacterium, Nocardia, and related taxa by thin-layer chromatographic analysis of whole-organism methanolysates. J Gen Microbiol 88, 200-204.

Minnikin, D. E., Collins, M. D. \& Goodfellow, M. (1979). Fatty acid and polar lipid composition in the classification of Cellulomonas, Oerskovia and related taxa. J Appl Bacteriol 47, 87-95.

Page, R. D. M. (1996). TREEVIEW: an application to display phylogenetic trees on personal computers. Comput Appl Biosci 12, 357-358.

Prauser, H. \& Falta, R. (1968). Phagensensibilität, ZellwandZusammensetzung und Taxonomie von Actinomyceten. $Z$ Allg Mikrobiol 8, 39-46 (in German).

Rhuland, L. E., Work, E., Denman, R. F. \& Hoare, D. S. (1955). The behavior of the isomers of $\alpha, \varepsilon$-diaminopimelic acid on paper chromatograms. J Am Chem Soc 77, 4844-4846.

Saddler, G. S., Tavecchia, P., Lociuro, S., Zanol, M., Colombo, L. \& Selva, E. (1991). Analysis of madurose and other actinomycete whole cell sugars by gas chromatography. J Microbiol Methods 14, 185-191.

Saintpierre-Bonaccio, D., Amir, H., Pineau, R., Tan, G. Y. A. \& Goodfellow, M. (2005). Amycolatopsis plumensis sp. nov., a novel bioactive actinomycete isolated from a New-Caledonian brown hypermagnesian ultramafic soil. Int $J$ Syst Evol Microbiol 55, 2057-2061. 
Saitou, N. \& Nei, M. (1987). The neighbor-joining method: a new method for constructing phylogenetic trees. Mol Biol Evol 4, 406-425.

Shirling, E. B. \& Gottlieb, D. (1966). Methods for characterization of Streptomyces species. Int J Syst Bacteriol 16, 313-340.

Takahashi, Y. (2001). Family Pseudonocardiaceae. In Identification Manual of Actinomycetes, pp. 227-239. Edited by The Society for Actinomycetes Japan. Tokyo: The Business Centre for Academic Societies.

Tan, G. Y. A., Ward, A. C. \& Goodfellow, M. (2006). Exploration of Amycolatopsis diversity in soil using genus-specific primers and novel selective media. Syst Appl Microbiol 29, 557-569.

Uchida, K. \& Aida, K. (1984). An improved method for the glycolate test for simple identification of the acyl type of bacterial cell walls. J Gen Appl Microbiol 30, 131-134.

Warwick, S., Bowen, T., McVeigh, H. \& Embley, T. M. (1994). A phylogenetic analysis of the family Pseudonocardiaceae and the genera Actinokineospora and Saccharothrix with $16 \mathrm{~S}$ rRNA sequences and a proposal to combine the genera Amycolata and Pseudoamycolata in an emended genus Pseudonocardia. Int J Syst Bacteriol 44, 293-299.

Wayne, L. G., Brenner, D. J., Colwell, R. R., Grimont, P. A. D., Kandler, O., Krichevsky, M. I., Moore, L. H., Moore, W. E. C., Murray,
R. G. E. \& other authors (1987). International Committee on Systematic Bacteriology. Report of the ad hoc committee on reconciliation of approaches to bacterial systematics. Int $J$ Syst Bacteriol 37, 463-464.

Wink, J. M., Kroppenstedt, R. M., Ganguli, B. N., Nadkarni, S. R., Schumann, P., Seibert, G. \& Stackebrandt, E. (2003). Three new antibiotic producing species of the genus Amycolatopsis, Amycolatopsis balhimycina sp. nov., A. tolypomycina sp. nov., A. vancoresmycina sp. nov., and description of Amycolatopsis keratiniphila subsp. keratiniphila subsp. nov. and A. keratiniphila subsp. nogabecina subsp. nov. Syst Appl Microbiol 26, 38-46.

Wink, J., Gandhi, J., Kroppenstedt, R. M., Seibert, G., Sträubler, B., Schumann, P. \& Stackebrandt, E. (2004). Amycolatopsis decaplanina sp. nov., a novel member of the genus with unusual morphology. Int J Syst Evol Microbiol 54, 235-239.

Yassin, A. F., Schaal, K. P., Brzezinka, H., Goodfellow, M. \& Pulverer, G. (1991). Menaquinone patterns of Amycolatopsis species. Zentralbl Bakteriol 274, 465-470.

Yassin, A. F., Haggenei, B., Budzikiewicz, H. \& Schaal, K. P. (1993). Fatty-acid and polar lipid-composition of the genus Amycolatopsis application of fast-atom-bombardment mass-spectrometry to structure-analysis of underivatized phospholipids. Int J Syst Bacteriol 43, $414-420$. 